\title{
IMPROVEMENT OF SERVICE OFFERING CONNECTED TO CUSTOMER SATISFACTION IN THE POWER ELECTRONICS FIELD
}

\author{
Jari Koskinen ${ }^{1}$, Daniel Sahebi ${ }^{1}$, Hassan Nikookar ${ }^{1}$, Wang Zhan $^{2}$ \\ 1 University of Vaasa, Department of Production/Industrial management, Finland \\ 2 The Key Laboratory of Contemporary Design and Integrated Manufacturing Technology, Ministry of Education, \\ Northwestern Polytechnical University, China
}

\author{
Corresponding author: \\ Jari Koskinen \\ Department of Production \\ Faculty of Technology \\ University of Vaasa \\ P.O. Box 700, FI-65101, Vaasa Finland \\ phone: +358408371217 \\ e-mail: jari.sakari.koskinen@gmail.com
}

Received: 26 March 2013 Accepted: 29 April 2013

\begin{abstract}
This research is a case study research related to customer satisfaction, focuses on more effective service improvement and changes in regards with meeting the customer needs. Through empirical approach and related enterprises investigation, based on employees' perspective and end-user' perspective, it designs a questionnaire system to collect data. In a case company, totally 31 interviews were made from 18 subsidiaries and 13 from end customers. Finally, we use statistical analysis to analysis the collection data and draw a conclusion. The outcomes of analysis show that communication and effective information flow, as well as effective service processes are the key while technical knowhow is the basic requirements. Throughout the body of the research, we can observe that there are significant differences between the internal and external customers perspective. These differences should be taken into consideration when the service improvement is the main objective. This research helps manufacturing firms to improve their value added services in addition to operating closer to their global customers.
\end{abstract}

KEYWORDS

customer satisfaction, industrial service offering, services quality improvement, dynamic capabilities.

\section{Introduction}

In the past few years, the challenge to raise the profit level has increased in many companies. Companies are striving to extend the value-added chain and work closed to the customers [1]. Currently, the service programs are of an immense importance in various manufacturing sectors. Stressing on customers' point of view related to service quality is crucial to increase the customers' satisfaction and to enhance the company's value added. With the improvement in customer's business situation, their requirements are changing from mass production to customization, with high regards to quality and flexibility levels. Therefore, it is important to improve firms dynamic capabilities by understanding the customer requirements and provide them with products and services they need, reduce the total cost and continually increase the customer's satisfaction.

Various manufacturing companies deliver their products along with offering after-sales services. One should always bear in mind that improving the operation strategy leads to an improve in the firm's efficiency globally. It also positively affects the aftersale services. Hence, manufacturing firms aim to market their products while endeavoring for a better relationship with the end customers through pro- 
viding higher quality after-sales service. After-sales services do indeed have a very important role in manufacturing firms, this is due to the fact that the trend of technology is exponentially growing and after-sales services enable the manufacturers to gain feedbacks about their product and service from customers. This is because of information flow from the customers back to the producers has drastic effects on the improvement for the quality of the items being produced. In the past few decades this method has been mainly used by the service department, however, with the advancement of technology in competitive markets, the manufacturing firms are also taking advantage of this method by the aim of improving the production quality as a whole.

Nowadays, customer loyalty as well as creating growth opportunities in markets are as important as selling the products. Under the circumstances of product technology and quality, after-sales services have become a more important factor affecting customer satisfaction degree. Currently, many manufacturing firms concentrate on improving customer satisfaction via deeper cooperation via after-sales service [2]. It is crucial to understand the needs of different customers and to improve company's after sales performance.

Various researches on customer satisfaction have focused on elements of quality and services. It is obvious that industrial services can have a large variety of demand characteristics with regards to volume, and that can affect the service design to be either centralized or decentralized. There is a need for more and better detailed investigation on analyzing industrial services offered by manufacturing companies.

This research paper is a case study, concentrating on more effective service improvement and changes with regards to meeting the customer needs and their satisfaction in the power electronics field.

The answer to the following questions is the main objective of our study:

Q1: Can there be correlation between the below listed factors affecting the overall satisfaction?

- Existing products;

- New generation products;

- Delivery;

- Service offering;

- Customer service.

Q2: To what percentage each of the above mentioned factors are affecting the overall customer satisfaction?

Q3: Are communication and service processes crucial in overall customer satisfaction?

\section{Literature review}

\section{Customer satisfaction and service quality}

Customer satisfaction is a direct result of providing goods and services as well as qualified information, which meet and exceed customers' needs. Many of the reclamations are related to company's Total Quality Management (TQM). It is worth mentioning that TQM had been widely used during the past few decades and is recently replaced by more advanced methods such as Mass Customization and Lean Production. Meeting customers' requirements, and consequently assuring customer satisfaction, are ultimately the responsibility and the main task of the manufacturing firms.

During the last decades the researchers have collected a number of studies on customer satisfaction and service quality. This case study focuses on the following dimensions:

(1) Focuses on the literature to explain the importance and necessity of customer satisfaction.

Bearden and Fornell, for instance, pointed out that customer satisfaction is directly linked to be resulted from repeat sales, positive spread of information, and customer loyalty $[4,5]$. Higher market share and profit can be driven from high customer satisfaction rate, which leads to a much stronger compatibility and competitive advantage [6]. Consequently one can claim that improvement in service quality, value perceived, and customer satisfaction results to more success and competitive advantage [7-11]. It is quite obvious that the customer satisfaction turns out to be the main objective of various manufacturing corporations.

(2) Discussion of various elements influencing customer satisfaction.

Anderson, Fomell, and Lehmann, believed that service value is one of the most crucial factors when it comes to customer satisfaction [2]. Zeithaml and Bitner found that customer satisfaction can be strongly affected by the following factors [12]:

- Service quality;

- Product quality;

- Price;

- Personal and situational factors.

Croninet et al. and Kristensen pointed out that customer satisfaction is heavily influenced by service quality $[13,14]$. Similar conclusions have been argued in the studies of website and online shopping [15-20]. These studies supported the view that service quality affects customer satisfaction in a somewhat positive way.

(3) Highlighting various methods for evaluating customer satisfaction and service quality. 
Meuter, Ostrom, Roundtree, and Bitner introduced diverse methods of customized service enhancements with the aim of increasing the customer satisfaction rate [21]. Christian and Bettina have introduced a scale to measure industrial customers' satisfaction. That scale can be used in different situations and various product categories [3].

\section{Relevant method for data analyzing}

Customer surveys are powerful tools for assessing customer satisfaction. These surveys put forward valuable data enabling a company to compare its performance with its competitors.

Statistical analysis method can be an effective tool for data analyses $[22,23]$. However, it is the fact that many items in the questionnaire for customer satisfaction surveys were unable of quantitative evaluation. Binshan Lin noticed that the main problem needs bringing deeper attention in customer satisfaction surveys [24]. When in accurate analyses are used, results may not be valid, and misleading conclusions may be drawn. In this case, incorrect conclusions could result in wrong decisions made by management.

\section{Research methodology}

Figure 1 shows that the research process and methodology in this paper, from questionnaire design to the conclusion of the results.

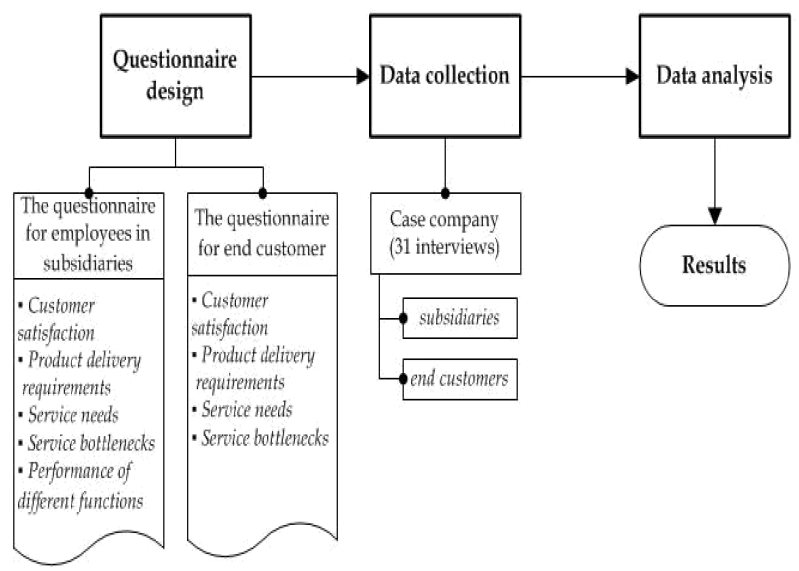

Fig. 1. Research process and methodology.

\section{Questionnaire design}

Customer satisfaction surveys have been used to measure the level of customer satisfaction. It is a fact that questionnaires are used as a common technique for assessing customer satisfaction.

The questionnaire has been developed by a consulting company and the case company's experts.
Data was collected in a global sales meeting that was held in Mexico in the year 2011.

The questionnaire contained two parts. The first part includes standard questions scaled from one to five where $1=$ "low" and $5=$ "high". The second part was dedicated to individual free comments given by respondents.

The questionnaire was designed for two groups. One is for managers and experts as internal customers in different subsidiaries, and one is for ultimate customers. The items of the questionnaire for internal customers are existing products, new generation products, delivery, service offering, and customer service. The items of the questionnaire for external customer are the same as internal ones.

\section{Data collection}

The case company is one of the biggest on its own business field in the world. Totally thirty one persons have been questioned consisting of 18 from subsidiaries and 13 from end customers.

\section{Data analysis}

SPSS has been the main tool for analyzing the statistical data collected from the questionnaire. The main methods used for analyzing the data were through the correlation and regression analysis. In this study we have used five following factors: existing products, new generation products, delivery, service offering and customer service (see Fig. 2) to measure customer satisfaction and calculated the mean value of them. Additionally, we noticed two extra

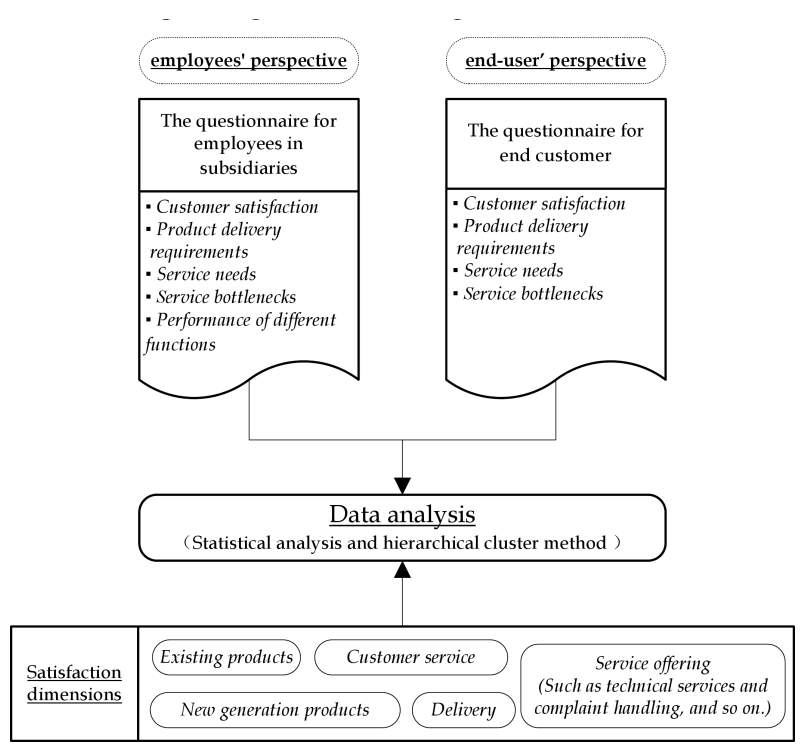

Fig. 2. Satisfaction dimensions use in the data analysis process. 
important factors which affected the customer satisfaction immensely. These two factors are effective communication and rapid service processes. Those areas can be counted as the key service processes to manufacturing firms. The results can help manufacturing firms to improve their value added services in addition to operating closer to their global customers.

\section{Results}

The found data from each and every questionnaire had been entered into SPSS and the correlation along with the regression between the main factors of the questionnaire had been calculated. It is worth mentioning that the main factors of the questionnaires are as following: existing products, new generation products, delivery, service offering and customer service. As we already know our questionnaires has been divided to two groups of external and internal customers. The following analysis and results are presented respectively.

\section{Correlation of the external customers}

Table 1 belongs to the correlation analysis of the questionnaires answered by the external customers. 12 questionnaires out of 13 were qualified enough to be analyzed. This is due to the fact that one of the questionnaires did not contain enough answers to be used by the SPSS program. From the Table 1 we can observe that which one of the factors are correlated with each other.

The numbers containing $* *$ indicate that the correlation between factors is 99 percent accurate. However if the sign above a number is * it is indicating that the existing correlation is 95 percent accurate. For instance there is a 72 percent correlation between the existing products and the new generation products.

\section{Regression analysis of the external customers}

As we can see from the Table 2, all the factors are significant, meaning that the regression analysis do indeed stand up amongst all the factors. It should however be mentioned that an extra factor has been created as the independent factor which is called the Overall Customer Satisfaction. The numbers in this factor are result of the mean of the values in all the other factors. One should note that the five other factors are indeed dependent factors. The beta column in the Table 2 shows the percentage, belonging to every factor and the role it has on the overall customer satisfaction. The percentage belonging to each factor is as following (refer to Fig. 3):

- Existing products 10\%;

- New generation products $15 \%$;

- Delivery $32 \%$;

- Service offering $44 \%$;

- Customer service $27 \%$.

Table 1

Correlations; external customers.

\begin{tabular}{|c|c|c|c|c|c|c|}
\hline & & $\begin{array}{l}\text { Existing } \\
\text { products }\end{array}$ & $\begin{array}{c}\text { New generation } \\
\text { products }\end{array}$ & Delivery & $\begin{array}{l}\text { Service } \\
\text { offering }\end{array}$ & $\begin{array}{c}\text { Customer } \\
\text { service }\end{array}$ \\
\hline \multirow[t]{3}{*}{ Existing products } & Pearson Correlation & 1 & $.722^{* *}$ & .312 & $.623^{*}$ & $.658^{*}$ \\
\hline & Sig. (2-tailed) & & .008 & .323 & .030 & .020 \\
\hline & $\mathrm{N}$ & 12 & 12 & 12 & 12 & 12 \\
\hline \multirow[t]{3}{*}{ New generation products } & Pearson Correlation & $.722^{* *}$ & 1 & -.152 & .409 & .207 \\
\hline & Sig. (2-tailed) & .008 & & .638 & .187 & .519 \\
\hline & $\mathrm{N}$ & 12 & 12 & 12 & 12 & 12 \\
\hline \multirow[t]{3}{*}{ Delivery_ } & Pearson Correlation & .312 & -.152 & 1 & .550 & $.623^{*}$ \\
\hline & Sig. (2-tailed) & .323 & .638 & & .064 & .031 \\
\hline & $\mathrm{N}$ & 12 & 12 & 12 & 12 & 12 \\
\hline \multirow[t]{3}{*}{ Service offering } & Pearson Correlation & $.623^{*}$ & .409 & .550 & 1 & .559 \\
\hline & Sig. (2-tailed) & .030 & .187 & .064 & & .059 \\
\hline & $\mathrm{N}$ & 12 & 12 & 12 & 12 & 12 \\
\hline \multirow[t]{3}{*}{ Customer service } & Pearson Correlation & $.658^{*}$ & .207 & $.623^{*}$ & .559 & 1 \\
\hline & Sig. (2-tailed) & .020 & .519 & .031 & .059 & \\
\hline & $\mathrm{N}$ & 12 & 12 & 12 & 12 & 12 \\
\hline
\end{tabular}

** Correlation is significant at the 0.01 level (2-tailed).

* Correlation is significant at the 0.05 level (2-tailed). 
Table 2

Coefficients.

\begin{tabular}{|c|c|c|c|c|c|c|}
\hline \multirow{2}{*}{\multicolumn{2}{|c|}{ Model }} & \multicolumn{2}{|c|}{ Unstandardized Coefficients } & \multirow{3}{*}{$\begin{array}{c}\text { Standardized Coefficients } \\
\text { Beta }\end{array}$} & \multirow{3}{*}{$\begin{array}{c}\mathrm{t} \\
.000\end{array}$} & \multirow{3}{*}{$\begin{array}{l}\text { Sig. } \\
1.000\end{array}$} \\
\hline & & \multirow{2}{*}{$\begin{array}{c}\text { B } \\
-8.327 \mathrm{E}-15 \\
\end{array}$} & \multirow{2}{*}{$\begin{array}{c}\text { Std. Error } \\
.000\end{array}$} & & & \\
\hline 1 & (Constant) & & & & & \\
\hline & Existing products & .200 & .000 & .101 & $8.937 \mathrm{E} 6$ & .000 \\
\hline & New generation products & .200 & .000 & .149 & $1.569 \mathrm{E} 7$ & .000 \\
\hline & Delivery_ & .200 & .000 & .323 & $4.029 \mathrm{E} 7$ & .000 \\
\hline & Service offering & .200 & .000 & .444 & $5.904 \mathrm{E} 7$ & .000 \\
\hline & Customer service & .200 & .000 & .272 & $3.221 \mathrm{E} 7$ & .000 \\
\hline
\end{tabular}

a. Dependent Variable: Overall satisfaction

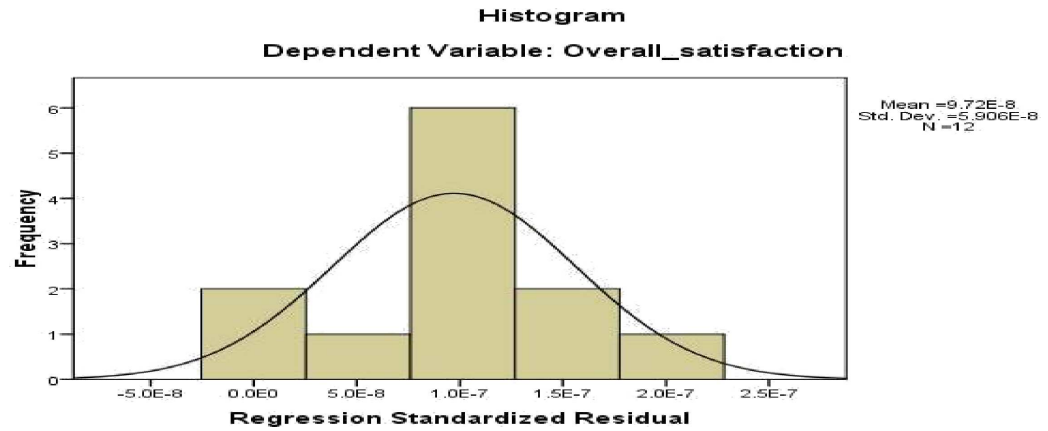

Fig. 3. Dependent variables of external customer satisfaction.

\section{Correlation of the internal customers}

The Table 3 belongs to the correlation analysis of the questionnaires belonging to the internal customers. 17 questionnaires out of 18 were qualified enough to be analyzed. This is due to the fact that one of the questionnaires did not contain enough answers to be used by the SPSS program. From the
Table 3 we can observe that which one of the factors are correlated with each other. The numbers containing ** indicate that the correlation between factors is 99 percent accurate. However if the sign above a number is $*$ it is indicating that the existing correlation is 95 percent accurate. However according to SPSS analysis for the internal customers, there is no correlation amongst any of the factors.

Table 3

Correlations; internal customers.

\begin{tabular}{ll|c|c|c|c|c}
\hline & & $\begin{array}{c}\text { Existing } \\
\text { products }\end{array}$ & $\begin{array}{c}\text { New generation } \\
\text { products }\end{array}$ & Delivery & $\begin{array}{c}\text { Service } \\
\text { offering }\end{array}$ & $\begin{array}{c}\text { Customer } \\
\text { service }\end{array}$ \\
\hline Existing products & Pearson Correlation & 1 & $.722^{* *}$ & .312 & $.623^{*}$ & $.658^{*}$ \\
& Sig. (2-tailed) & & .008 & .323 & .030 & .020 \\
& $\mathrm{~N}$ & 17 & 17 & 17 & 17 & 17 \\
\hline New generation products & Pearson Correlation & $.512^{* *}$ & 1 & -.134 & .632 & .207 \\
& Sig. (2-tailed) & .008 & & .638 & .154 & .519 \\
& $\mathrm{~N}$ & 17 & 17 & 17 & 17 & 17 \\
\hline Delivery- & Pearson Correlation & .312 & -.152 & 1 & .550 & $.623^{*}$ \\
& Sig. (2-tailed) & .323 & .638 & & .064 & .031 \\
& $\mathrm{~N}$ & 17 & 17 & 17 & 17 & 17 \\
\hline Service offering & Pearson Correlation & $.673^{*}$ & .534 & .542 & 1 & .508 \\
& Sig. (2-tailed) & .030 & .187 & .064 & & .059 \\
& $\mathrm{~N}$ & 17 & 17 & 17 & 17 & 17 \\
\hline Customer service & Pearson Correlation & $.678^{*}$ & .265 & $.623^{*}$ & .559 & 1 \\
& Sig. (2-tailed) & .013 & .532 & .051 & .063 & 17 \\
& $\mathrm{~N}$ & 17 & 17 & 17 & 17 & 17 \\
\hline
\end{tabular}

** Correlation is significant at the 0.01 level (2-tailed).

* Correlation is significant at the 0.05 level (2-tailed). 


\section{Regression analysis the internal customers}

As we can see from the Table 4, all the factors are significant, meaning that the regression analysis do indeed stand up amongst all the factors. Once again an extra factor has been created as the independent factor which is called the Overall Customer Satisfaction. The numbers in this factor are result of the mean of the values in all the other factors. One should note that the five other factors are indeed de- pendent factors. The beta column in the table below shows the percentage, belonging to every factor and the role it has on the overall customer satisfaction. The percentage belonging to each factor is as following( refer to Fig. 4):

- Existing products $18 \%$;

- New generation products $25 \%$;

- Delivery 34\%;

- Service offering $43 \%$;

- Customer service $30 \%$.

Table 4

Coefficients.

\begin{tabular}{|c|c|c|c|c|c|c|}
\hline \multirow{2}{*}{\multicolumn{2}{|c|}{ Model }} & \multicolumn{2}{|c|}{ Unstandardized Coefficients } & \multirow{2}{*}{$\begin{array}{c}\text { Standardized Coefficients } \\
\text { Beta }\end{array}$} & \multirow{2}{*}{$\mathrm{t}$} & \multirow{2}{*}{ Sig. } \\
\hline & & $\mathrm{B}$ & Std. Error & & & \\
\hline \multirow[t]{6}{*}{1} & (Constant) & $6.661 \mathrm{E}-16$ & .000 & & .000 & 1.000 \\
\hline & Existing products & .200 & .000 & .180 & $5.155 \mathrm{E} 7$ & .000 \\
\hline & New generation products & .200 & .000 & .256 & $8.160 \mathrm{E} 7$ & .000 \\
\hline & Delivery_ & .200 & .000 & .342 & $1.048 \mathrm{E} 8$ & .000 \\
\hline & Service offering & .200 & .000 & .434 & $1.131 \mathrm{E} 8$ & .000 \\
\hline & Customer service & .200 & .000 & .305 & $6.776 \mathrm{E} 7$ & .000 \\
\hline
\end{tabular}

a. Dependent Variable: Overall satisfaction

Histogram

Dependent Variable: Overal_satisfaction

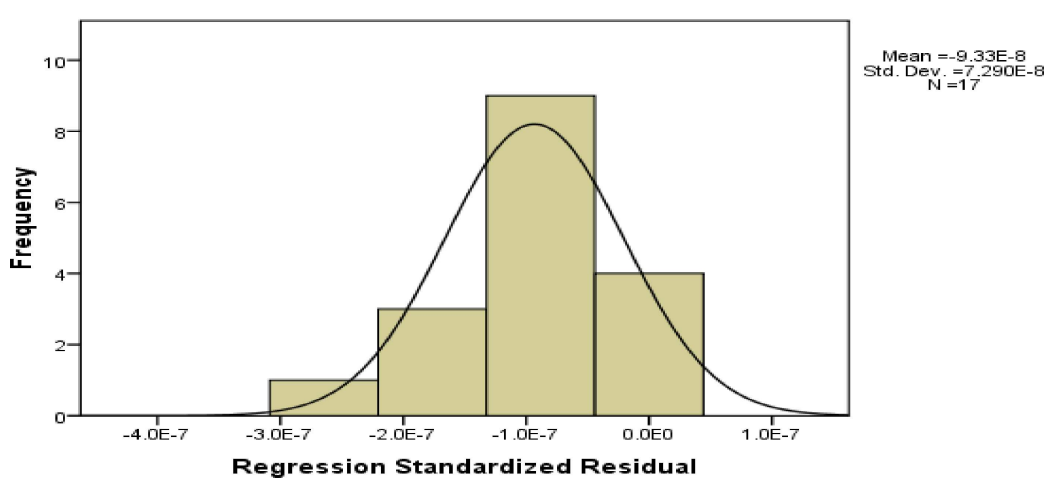

Fig. 4. Dependent variables of internal customer satisfaction.

Table 5

Free comments.

\begin{tabular}{l|c|c|c}
\hline Comments on Service offering and Customer service & Internal & End Customer & Total \\
\hline Communication improvement & 8 & 10 & 18 \\
• Responsiveness & & & \\
- Difficult to contact \\
• Information flow \\
- Information availability \\
• $24 / 7$ reachable
\end{tabular}


According to results of the analysis is SPSS, The delivery factor had a negative correlation with the new generation products. This is why Fig. 4 has only four columns.

According to the Table 5, the communication and service process improvement are extremely important for companies functioning on international scale. As we can see from Table 5, the communication factor happens to be the most important factor for the end customers. This is due to the fact that getting $24 / 7$ customer service is very valuable for end customers all over the world, in case a problem occurs unexpectedly. However according to the internal customers service process improvement happens to be the most important factor. This might be because of the fact that more documentation and tools are needed in the subsidiaries for supporting the customers at the best positive way.

\section{Discussion and conclusion}

Our study has certain limitations due to the fact that only one company was taken into consideration, with a limited amount of customer respondents. Further research is needed on the rapid service process improvement as a consequence of its crucial role on enhancing the company capabilities for dealing with various customer demands.

As we could see throughout the article, the main objective of this case study has been revolving around the factors which can affect the customer satisfaction. This could be valuable when companies prepare their service strategies. The process of gathering information has been taken care of by the use of questionnaires which have mainly covered the five main concern of our analysis. These main concerns or groups were as following:

- Existing products;

- New generation products;

- Delivery;

- Service offering;

- Customer service.

During the analysis of the gathered data a specific statistical data processing program, named SPSS, was used to sort out the data and help us with finding the correlation between the factors and the concepts affecting the customer satisfaction. During the studies, the main concern of the research had been finding out how and to what degree the service offering can affect and be linked to customer satisfaction. During our analysis we found out that according to the external customers there is indeed a correlation between the main five factors of the questionnaire (refer to Table 1 and 3). However, the internal customers believed that there is no positive correlation between mentioned factors. This might be due to the new generation products, being made of complete new components and the product development is based on new innovations. As it was stated in the body of this article, the respond to the questionnaire came from two different groups. One group of respondents was the internal customers who were the managers and experts of the daughter companies in various countries. The other group of respondents belonged to the end customers. It is worth mentioning once again that the five stated above factors were taken into consideration according to the influence they have on the overall customer satisfaction.

The internal customers ranked service offering to be the most important factor affecting the overall customer satisfaction. According to our data analysis from the internal customers, service offering affected the customer satisfaction by $43 \%$. In accordance with the calculations we made about the role of service offering according to the external customers, it affects the overall customer satisfaction by $44 \%$. It is also worth mentioning that the biggest percentage out of five was belonging to service offering itself.

Based on the analysis from Table 5, we can conclude that effective communication and rapid service processes have positive effects on the dynamic capabilities of the company.

The authors would like to thank Prof. Josu Takala for his great support. The fourth author gratefully acknowledges the support of China Scholarship Council.

\section{References}

[1] Karlson U., Service based manufacturing strategies implications for product development, productions and service operations in global companies, In: Proceedings of the POMS College of Service Operations and EurOMA conference, 12-13 July, London, 2007.

[2] Anderson E.W., Fornell C., Lehmann D.R., Customer satisfaction, market share and profitability: Findings from Sweden, Journal of Marketing, 58, 58-66, 1994.

[3] Christian Homburga, Bettina Rudolph, Customer satisfaction in industrial markets: dimensional and multiple role issues, Journal of Business Research, 52, 15-33, 2001 
[4] Bearden W.O., Teel J.E., Selected determinants of consumer satisfaction and complaint reports, J. Mark. Res., 20, 21-8, February 1983.

[5] Fornell C., Johnson M.D., Anderson E.W., Cha J., Bryant B.E., The American customer satisfaction index: nature, purpose and findings, J. Mark., 60, 7-18, October 1996.

[6] Fornell C., A national customer satisfaction barometer: The Swedish experience, Journal of Marketing, 56, 6-21, January 1992.

[7] Khatibi A.A., Ismail H., Thyagarajan.V., What drives customer loyalty: An analysis from the telecommunications industry, Journal of Targeting, Measurement and Analysis for Marketing, 11 (1), 34-44, 2002.

[8] Patterson P.G., Spreng R.A., Modeling the relationship between perceived value, satisfaction and repurchase intentions in a business-to-business, services context: An empirical examination, International Journal of Service Industry Management, 8 (5), 414-434, 1997.

[9] Landrum H., Prybutok V.R., A service quality and success model for the information service industry, European Journal of Operational Research, 156 (3), 628-642, 2004.

[10] Wang Y., Lo H.P., Yang Y., An integrated framework for service quality, customer value, satisfaction: Evidence from China's telecommunication industry, Information Systems Frontiers, 6 (4), 325340, 2004.

[11] Westbrook R.A., Product/consumption-based affective responses and post purchase processes, Journal of Marketing Research, 24 (3), 258-270, 1987.

[12] Zeithaml V.A., Bitner M.J., Service marketing: integrating customer focus across the firm (2nd ed.), New York: McGraw-Hill Company, Inc., 2000.

[13] Cronin J.J., Jr., Brady, Michael K., Tomas G., Hult M., Assessing the effects of quality, value and customer satisfaction on consumer behavioral intentions in service environments, Journal of Retailing, 76 (2), 19-218, 2000.
[14] Kristensen K., Martensen A., Gronholdt L., Measuring the impact of buying behavior on customer satisfaction, Total Quality Management, 10 (4/5), 602-614, 1999.

[15] Bauer H.H., Falk T., Hammerschmidt M., eTransQual: A transaction process-based approach for capturing service quality in online shopping, Journal of Business Research, 59 (7), 866-875, 2006.

[16] Collier J.E., Bienstock C.C., Measuring service quality in e-retailing, Journal of Service Research, 8 (3), 260-275, 2006.

[17] Hsu H., An empirical study of web site quality, customer value, and customer satisfaction based on eshop, The Business Review, 5 (1), 190-193, 2006.

[18] Kuo Y.F., A study on service quality of community websites, Total Quality Management and Business Excellence, 14 (4), 461-473, 2003.

[19] Lee G.G., Lin H.F., Customer perceptions of eservice quality in online shopping, International Journal of Retail and Distribution Management, 33 (2/3), 161-176, 2005.

[20] Park C.H., Kim Y.G., The effect of information satisfaction and relational benefit of consumers' online shopping site commitments, Journal of Electronic Commerce in Organizations, 4 (1), 70-90, 2006.

[21] Meuter M.L., Ostrom A.L., Roundtree R.I., Bitner M.J., Self-service technologies: understanding customer satisfaction with technology-based service encounters, Journal of Marketing, 64 (3), 50-41, 2000.

[22] Torres-Corona, Susana Aranzazu, Attitudes toward People with Physical Disabilities and Accommodations, ProQuest, Inc., 2008.

[23] Jeremy Miles, Mark Shevlin, Applying Regression and Correlation: A Guide for Students and Researchers, SAGE Inc., 2001.

[24] BinshanLin, Charlotte A. Jones., Some issues in conducting customer satisfaction surveys, Journal of Marketing Practice: Applied Marketing Science, 3, 1, 4-13, 1997. 